\title{
Abiotic reduction mechanism of $A s(V)$ by fulvic acid in the absence of light and the effect of $\mathrm{Fe}$ (III)
}

\author{
Tsanangurayi Tongesayi ${ }^{1 *}$ and Ronald B Smart ${ }^{2}$ \\ ${ }^{1}$ Monmouth University, Department of Chemistry, Medical Technology and Physics, 400 Cedar Avenue, West Long Branch, NJ 07764 \\ ${ }^{2}$ West Virginia University, Department of Chemistry, PO Box 6045, Morgantown, WV 26506-6045
}

\begin{abstract}
In this paper, the mechanism of the redox cycling of arsenic under dark conditions was studied to help explain the high prevalence of As(III) in groundwater where no photochemical redox cycling is expected to occur. Most research has focused on the photochemical oxidation and reduction of metals and metal ions with dark redox cycling not given as much attention. A full understanding of the geochemical cycle and speciation of arsenic makes it equally important to study reduction of $\mathrm{As}(\mathrm{V})$ to As(III) under dark conditions.

The reduction of $\mathrm{As}(\mathrm{V})$ by FA in the absence of light is hypothesised to occur via complexation, which can be greatly enhanced by the presence of iron. $\mathrm{Fe}(\mathrm{III})$ is envisaged to play two roles:

- It facilitates binding of arsenate by FA through intermetallic bridging which results in the reduction of $\mathrm{As}(\mathrm{V})$ to the intermediate As(IV).

- It can be reduced by FA to Fe(II) which then can reduce As(IV) to As(III). The reduction of $\mathrm{As}(\mathrm{V})$ is felt to occur in two one-electron steps, where the As(IV) is reduced by $\mathrm{Fe}(\mathrm{II})$.

In solutions with no added Fe(III), binding of the negative arsenate by the negative FA occurs through inter-metallic bridging by cationic metals inherent in the FA. Competition from $\mathrm{H}^{+}$ions for the binding sites on FA at lower $\mathrm{pH}$ results in the diminished reduction.
\end{abstract}

Keywords: abiotic reduction, mechanism, As(V), fulvic acid, Fe(III)

\section{Introduction}

Our previous study has demonstrated that $\mathrm{As}(\mathrm{V})$ can be reduced to As(III) by fulvic acid (FA) under both light and dark conditions in the presence and absence of Fe(III) (Tongesayi and Smart, 2006). This means that photochemical reduction is not the only mechanism by which As(V) can be reduced to As(III) by FA.

Most previous research (Wittbrodt et al., 1996; Hug et al., 1997; Fukushima et al., 1999; Gaberell et al., 2003; Dutta et al., 2005) has focused on photochemical Fe(III)-mediated oxidation or reduction of heavy metals in natural waters; however, redox cycling under dark conditions has not been given as much attention. Also the development of technologies to remove arsenic species from drinking water has attracted intense research efforts (Thirunavukkarasu et al., 2003). This work is important in groundwater systems where the presence of DOM and iron may result in As(III) contamination.

\section{Materials and methods}

Suwannee River Fulvic Acid (FA) was obtained from the International Humic Substances Society (IHHS) collection of reference humic materials. The $\mathrm{As}(\mathrm{V})$ solutions were prepared from SPEX Certiprep, Inc. (Metuchen, NJ) PEAS2-2X $1000 \mathrm{mg} / \ell$ $\mathrm{As}(\mathrm{V})$ in $2 \% \mathrm{HNO}_{3}$ in which $\mathrm{As}(\mathrm{V})$ was in the arsenate $\left(\mathrm{AsO}_{4}^{3-}\right)$ form, and the $\mathrm{As}$ (III) stock solution was prepared from $\mathrm{As}_{2} \mathrm{O}_{3}$ Fisher Scientific Certified (Chicago, IL). Fe(III) stock solution was prepared from iron(III) sulphate puratronic, $99.999 \%$ metal basis

* To whom all correspondence should be addressed.

용 (732) 263-5627; fax: (732) 263-5213;

e-mail: ttongesa@monmouth.edu

Received 22 June 2007; accepted in revised form 17 August 2007. from Alfa Aesar (Ward Hill, MA).

Amberlite-XAD-8 20-50 mesh (Fluka AG, Cheische Fabrik CH-9470 Buchs, Switzerland) was packed in an opaque glass column and was used to separate FA from the arsenic species before analysis (Tongesayi and Smart, 2006). Acid-washed (10\% $\mathrm{HNO}_{3}$ ) and oven-dried $\left(160\right.$ to $\left.170^{\circ} \mathrm{C}\right)$ glassware and reagent-grade or higher chemicals (Fisher Scientific, Chicago, IL) were used in all experiments and all solutions were prepared with Milli-Q (millipore, Billerica, MA) deionised distilled water. All glassware was rinsed with $70 \%$ isopropyl alcohol before use. $\mathrm{HCl}$ (optima) and $\mathrm{NaOH}$ $(50 \% \mathrm{w} / \mathrm{w})$ were used for all $\mathrm{pH}$ adjustments as appropriate.

Nalgene Amber high density (HDPE) bottles (60 Ml, Fisher Scientific, Chicago, IL), acid-washed $\left(10 \% \mathrm{HNO}_{3}\right)$ and rinsed with $70 \%$ isopropyl alcohol were used for dark incubation reactions. Temperature was maintained constant during incubations using an Isotemp Immersion Circulator from Fisher Scientific. A model $2100 \mathrm{pH} / \mathrm{Temp} / \mathrm{mV}$ meter (VWR Scientific Products, West Chester, PA) was used to measure the $\mathrm{pH}$ of solutions.

\section{Reaction incubations}

Aliquots from a stock solution of FA were equilibrated at the appropriate $\mathrm{pH}$ for $24 \mathrm{~h}$ prior to being spiked with a known concentration of $\mathrm{As}(\mathrm{V})$. Reaction mixtures in which $\mathrm{Fe}(\mathrm{III})$ was included were initially incubated for $24 \mathrm{~h}$ with only FA and $\mathrm{Fe}(\mathrm{III})$ in order to prevent precipitation of Fe. They were then equilibrated at an appropriate $\mathrm{pH}$ for $24 \mathrm{~h}$ before being spiked with a known concentration of $\mathrm{As}(\mathrm{V})$.

$\mathrm{HC1}$ (Fisher Optima, Chicago, IL) or $\mathrm{NaOH}(50 \%$ W/W Fisher Certified, Chicago, IL) were used to adjust the $\mathrm{pH}$ of the reaction mixtures as appropriate. No buffer was added to the reaction mixtures as it was felt that this could alter the chemistry of FA. As a result, $\mathrm{pH}$ was periodically adjusted especially at higher $\mathrm{pH}$ 
$(\mathrm{pH}>4)$ where $\mathrm{pH}$ slightly decreased with time. The incubated mixtures were examined after specific reaction times. Blanks were treated the same and the experiments were run in triplicate.

\section{Arsenic analyses}

The effect of each experimental parameter on the reduction of $\mathrm{As}(\mathrm{V})$ was inferred from the measured concentration of As(III). Square wave cathodic stripping voltammetry (SWCSV) at a hanging mercury drop electrode was employed using a BAS $100_{B}$ Electrochemical Analyzer (Bioanalytical Systems, Inc., West Lafayette, IN) coupled to a BAS Controlled Growth Mercury Electrode (Tongesayi and Smart, 2006).

\section{Determination of $\mathrm{Fe}(\mathrm{II})$}

Samples for $\mathrm{Fe}(\mathrm{II})$ analyses were prepared using the o-phenanthroline method. The prepared samples were then analysed using $\mathrm{UV} / \mathrm{V}$ is spectrophotometry at $500 \mathrm{~nm}$ using the standard addition method.

\section{Results and discussion}

As shown in Fig. 1, substantial reduction of $\mathrm{As}(\mathrm{V})$ by FA occurs in the dark at $\mathrm{pH}$ 6. This suggests that photochemical reduction is not the only abiotic mechanism responsible for the production of As(III). The amount of reduction has also been shown to increase with an increase in FA concentration (see Appendix).

In order to determine the effect of iron on the reduction of $\mathrm{As}(\mathrm{V})$ by $\mathrm{FA}$ at $\mathrm{pH} 3$ and 6 , known amounts of Fe(III) were added to the reaction mixtures of $\mathrm{As}(\mathrm{V})$ and FA. The rate of $\mathrm{As}(\mathrm{V})$ reduction, $\mathrm{r}$, can be written as shown in Eq. (1):

$$
\mathrm{r}=-\mathrm{d}[\mathrm{As}(\mathrm{V})] / \mathrm{dt}=\mathrm{k}_{\mathrm{obs}}[\operatorname{As}(\mathrm{V})]
$$

where:

$\mathrm{k}_{\mathrm{obs}}$ is the pseudo first-order rate constant

The $[\mathrm{As}(\mathrm{V})]_{\mathrm{t}}$ at incubation time, $\mathrm{t}$, was obtained by subtract-

ing the $[\mathrm{As}(\mathrm{III})]$ measured from the initial $[\mathrm{As}(\mathrm{V})]_{\text {i }}$

As shown in Table 1, the addition of Fe(III) increased the rate of $\mathrm{As}(\mathrm{V})$ reduction compared to the rate in the absence of $\mathrm{Fe}(\mathrm{III})$ at both $\mathrm{pH}$, but the effect of $\mathrm{Fe}(\mathrm{III})$ is more pronounced at $\mathrm{pH} 3$.

It has been reported that both humic and fulvic acid form complexes with arsenic (Mukhopadhyay and Sanyal, 2004). Because of their different charges, Fe(III) and $\mathrm{As}(\mathrm{V})$ will likely bind non-competitively at different sites on FA and also be noncompetitively reduced by FA. This binding of the negatively charged As $(\mathrm{V})$ and negatively charged FA has been suggested to occur through ternary complexation with cationic metals inherently present in the FA, and the higher the metal content the greater the extent of complexation (Redman et al., 2002).

As shown in Fig. 2, no As(III) was found prior to $120 \mathrm{~h}$ of incubation of $\mathrm{As}(\mathrm{V})$ in the absence of iron at $\mathrm{pH} 2$, whereas in the presence of $\mathrm{Fe}(\mathrm{III})$ a small amount of $\mathrm{As}$ (III) was produced after $24 \mathrm{~h}$. As the amount of $\mathrm{Fe}(\mathrm{III})$ was increased from $2 \mu \mathrm{M}$ to $250 \mu \mathrm{M}$, a concurrent increase in the amount of As(III) was also observed after $24 \mathrm{~h}$. After incubation times of 120 and $700 \mathrm{~h}$ in the absence of $\mathrm{Fe}(\mathrm{III})$, more As(III) was produced than when $\mathrm{Fe}(\mathrm{III})$ was added. This suggests that although $\mathrm{Fe}(\mathrm{III})$ is essential to the reduction of $\mathrm{As}(\mathrm{V})$, the net production of $\mathrm{As}(\mathrm{III})$ must depend on the relative rates of the reduction of $\mathrm{As}(\mathrm{V})$ and the re-oxidation of the As(III) produced. The redox reaction of dissolved organic matter (DOM) and many metal redox

\begin{tabular}{|c|c|c|}
\hline \multicolumn{3}{|c|}{$\begin{array}{l}\text { TABLE } 1 \\
\text { The effect of pH and } \mathrm{Fe}(\mathrm{III}) \text { on the reduction of } \mathrm{As}(\mathrm{V}) \\
\text { by } \mathrm{FA} \text {. Initial reaction conditions: } 0.75 \mathrm{mg} / \mathrm{l} \mathrm{FA}, 0.50 \\
\mu \mathrm{M} \mathrm{As}(\mathrm{V}), 2.2 \mu \mathrm{M} \mathrm{Fe}(\mathrm{III}), 25^{\circ} \mathrm{C} \text {. ( } \mathrm{K}_{\mathrm{obs}} \text { values are averages } \\
\text { and standard deviations are too small to be included). }\end{array}$} \\
\hline $\mathrm{pH}$ & \multicolumn{2}{|c|}{$\mathrm{k}_{\mathrm{obs}} / \mathrm{min}$} \\
\hline 3 & $4.3 \times 10^{-5}$ & $1.2 \times 10^{-5}(\mathrm{no} \mathrm{Fe}(\mathrm{III}))$ \\
\hline 4 & $8.7 \times 10^{-5}$ & \\
\hline 5 & $3.0 \times 10^{-4}$ & \\
\hline 6 & $6.0 \times 10^{-4}$ & $4.1 \times 10^{-4}(\mathrm{no} \mathrm{Fe}(\mathrm{III}))$ \\
\hline 7 & $5.8 \times 10^{-4}$ & \\
\hline
\end{tabular}

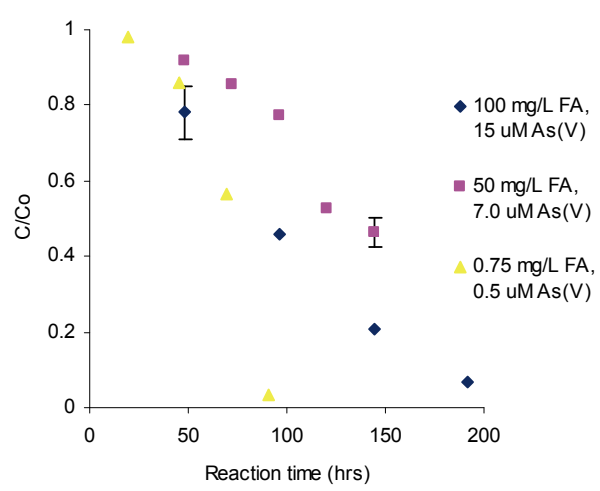

Figure 1

Fraction of $A s(V)\left(C / C_{d}\right)$ remaining as a function of time at $\mathrm{pH}$ 6. Analysis was done in triplicate and error bars represent the standard deviations. Standard deviation is within symbol size for data without error bars.

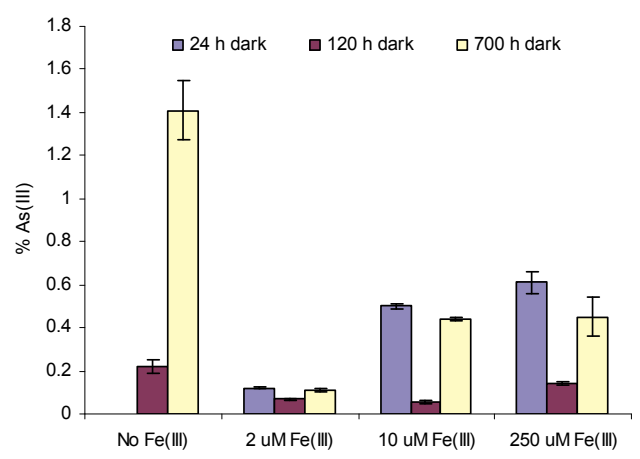

Figure 2

Percent As(III) produced by reduction of As(V) by FA at pH 2 and $28.8^{\circ} \mathrm{C}$ in the function of [Fe(III)]. Initial reaction conditions: $100 \mathrm{mg} / \mathrm{l}$ FA standard, $15 \mu \mathrm{M}$ As(V). Analysis was done in triplicate and error bars represent the standard deviations. Standard deviation is within symbol size for data without error bars.

couples have been reported to occur via one-electron transfer steps (Wittbrodt et al., 1996). Therefore, it seems likely that the first step in the reduction of As(V) to As(III) by FA should involve the unstable intermediate As(IV). Klaening et al. (1989) have reported the existence of As(IV) and observed that its rates of formation and disappearance are comparable.

In our experiments, it can be hypothesised that the fate of As (IV) depends on the reaction conditions. Fe(III) can oxidise $\mathrm{As}(\mathrm{IV})$ but any $\mathrm{Fe}(\mathrm{II})$ produced in that reaction can also reduce the As(IV) back to As(III), as shown in Eq. (2) and Eq. (3) respectively, which implies that the relative ratio of $\mathrm{Fe}(\mathrm{II}) /$ $\mathrm{Fe}(\mathrm{III})$ plays a very significant role in the net reduction of $\mathrm{As}(\mathrm{V})$ because the rates of these two reactions are similar (Emett and Khoe, 2001). The reaction represented by Eq. (2) does not occur 
in the absence of Fe(III). This could explain the accumulation of $\mathrm{As}(\mathrm{III})$ in the absence of Fe(III) after incubation times of $120 \mathrm{~h}$ and $700 \mathrm{~h}$ as shown in Fig. 2.

$$
\begin{aligned}
& \mathrm{As}^{4+}+\mathrm{Fe}^{3+} \rightarrow \mathrm{As}^{5+}+\mathrm{Fe}^{2+} \\
& \mathrm{As}^{4+}+\mathrm{Fe}^{2+} \rightarrow \mathrm{As}^{3+}+\mathrm{Fe}^{3+}
\end{aligned}
$$

At $\mathrm{pH} 2$ about $80 \%$ of the $\mathrm{Fe}(\mathrm{III})$ is reduced to $\mathrm{Fe}(\mathrm{II})$ by FA after $24 \mathrm{~h}$ as shown in Fig. 3. Voelker and Stulzberger(1996) reported approximately $70 \%$ reduction of $\mathrm{Fe}(\mathrm{III})$ after $100 \mathrm{~min}$ at $\mathrm{pH}$ 3 with similar concentrations of $\mathrm{Fe}(\mathrm{III})$ and FA. This implies that the $\mathrm{Fe}(\mathrm{II}) / \mathrm{Fe}(\mathrm{III})$ ratio is high and the reduction of $\mathrm{As}(\mathrm{IV})$ $\{\mathrm{As}(\mathrm{IV})+\mathrm{Fe}(\mathrm{II}) \rightarrow \mathrm{As}(\mathrm{III})+\mathrm{Fe}(\mathrm{III})\}$ should occur; however, less than $1.5 \% \mathrm{As}(\mathrm{III})$ was produced at $\mathrm{Fe}(\mathrm{III})$ concentrations ranging from 2 to $250 \mu \mathrm{M}$.

At pH $2 \mathrm{Fe}(\mathrm{III})$ is present in the form $\mathrm{FeOH}^{2+}, \mathrm{As}(\mathrm{V})$ is present as $\mathrm{H}_{3} \mathrm{AsO}_{4} / \mathrm{H}_{2} \mathrm{AsO}_{4}^{-}$(Cherry et al., 1979), and FA will be highly protonated, yet might still retain some negative charge. The addition of iron to FA produces the $\{\mathrm{Fe}$ (III)-FA\} complex (Voelker and Sulzberger, 1996; Bryan et al., 1997), which could facilitate the binding of $\mathrm{As}(\mathrm{V})$ by FA through inter-metallic bridging. This could then increase the reduction of $\mathrm{As}(\mathrm{V})$ by FA as shown in Eq. (4):

$$
\begin{aligned}
& \mathrm{FA}_{\text {red }}+\mathrm{Fe}(\mathrm{III}) \rightarrow\left\{\mathrm{Fe}(\mathrm{III})-\mathrm{FA}_{\mathrm{red}}\right\} \stackrel{\mathrm{As}(\mathrm{V})}{\rightarrow}\left\{\mathrm{As}(\mathrm{V})-\mathrm{Fe}(\mathrm{III})-\mathrm{FA}_{\text {red }}\right\} \\
& \rightarrow\left\{\mathrm{As}(\mathrm{IV})-\mathrm{Fe}(\mathrm{II})-\mathrm{FA}_{\text {ox }}\right\} \rightarrow\left\{\mathrm{As}(\mathrm{III})-\mathrm{Fe}(\mathrm{III})-\mathrm{FA}{ }_{\text {ox }}\right\} \text { (4) }
\end{aligned}
$$

Alternatively, the iron might also bind the $\mathrm{As}(\mathrm{V})$ forming a positively charged complex $\{\mathrm{As}(\mathrm{V})-\mathrm{Fe}(\mathrm{III})\}$. This is then bound by FA as the $\left\{\mathrm{As}(\mathrm{V})-\mathrm{Fe}(\mathrm{III})-\mathrm{FA}_{\text {red }}\right\}$ complex resulting in the reduction of $\mathrm{As}(\mathrm{V})$. This complex formation would explain the increased rate of $\mathrm{As}(\mathrm{III})$ production in the presence of $\mathrm{Fe}(\mathrm{III})$ and the extent of $A s(V)$ reduction would then depend on the formation of these complexes.

The formation of these complexes will be limited by $\mathrm{H}^{+}$competition for FA at $\mathrm{pH} \mathrm{2,} \mathrm{and} \mathrm{as} \mathrm{a} \mathrm{result,} \mathrm{the} \mathrm{rate} \mathrm{of} \mathrm{reduction} \mathrm{of}$ As(V) will be low. The large amount of $\mathrm{Fe}(\mathrm{II})$ produced together with the small amount of As(III) generated suggests that the Fe(II) is unable to reduce the $\mathrm{As}(\mathrm{V})$ at this $\mathrm{pH}$, but can reduce the $\mathrm{As}(\mathrm{IV})$ intermediate. As a result, if experimental conditions do not favour the production of As(IV) in solution, which should occur after the binding of $\mathrm{As}(\mathrm{V})$ by FA, very little or no $\mathrm{As}(\mathrm{III})$ will be generated.

The situation is different at higher $\mathrm{pH}$, where $\mathrm{FA}$ can reduce $\mathrm{As}(\mathrm{V})$ even in the absence of added $\mathrm{Fe}(\mathrm{III})$. In the presence of $\mathrm{Fe}(\mathrm{III})$, the $\mathrm{Fe}(\mathrm{II})$ produced will increase the rate of $\mathrm{As}(\mathrm{V})$ reduction by most likely acting on the intermediate As(IV). Although less $\mathrm{Fe}(\mathrm{II})$ was generated at $\mathrm{pH}$ 6, more $\mathrm{As}(\mathrm{III})$ was produced than at $\mathrm{pH} 2$ under the same initial conditions as shown in Fig. 3. At higher $\mathrm{pH}$, both $\mathrm{As}(\mathrm{V})\left(\mathrm{H}_{2} \mathrm{AsO}_{4}{ }^{-} / \mathrm{HAsO}_{4}{ }^{2-}\right)$ and $\mathrm{FA}$ are more negatively charged and a larger fraction of the added iron will be bound by FA.. Therefore, more complex formation occurs through inter-metallic bridging, which results in higher reduction rates.

The values of $\mathrm{k}_{\text {obs }}$ shown in Fig. 4 decreased as the As(V) concentration increased, which implies that the reaction does not follow first-order kinetics. Reduction via complex formation implies that FA-As(V) and FA-Fe(III) should represent intermediates. Since the FA concentration is constant, the FA/As(V) ratio decreases with the initial concentration of $\mathrm{As}(\mathrm{V})$ which results in the apparent decrease in the reduction rate.

\section{Conclusion}

Abiotic reduction of $\mathrm{As}(\mathrm{V})$ to the more toxic $\mathrm{As}(\mathrm{III})$ by FA has been shown to occur to a significant extent in dark conditions

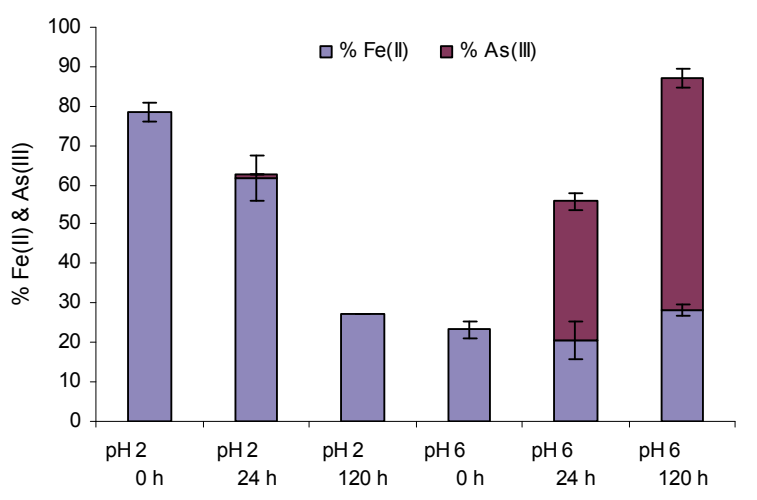

Figure 3

Percent $\mathrm{Fe}(\mathrm{II})$ and $\mathrm{As}$ (III) produced in a mixture containing $100 \mathrm{mg} / \mathrm{l} \mathrm{FA}, 15 \mu \mathrm{M} \mathrm{As}(\mathrm{V})$, and $250 \mu \mathrm{M} \mathrm{Fe}(\mathrm{III})$ at $28.8^{\circ} \mathrm{C}$ under dark conditions. The value for $\% \mathrm{Fe}(\mathrm{II})$ is the height of the blue bar and the value for \% As(III) is the height of the red bar (above the blue bar). Analysis was done in triplicate and error bars represent the standard deviations. Standard deviation is within symbol size for data without error bars. (Time was recorded after addition of $A s(V)$ ).

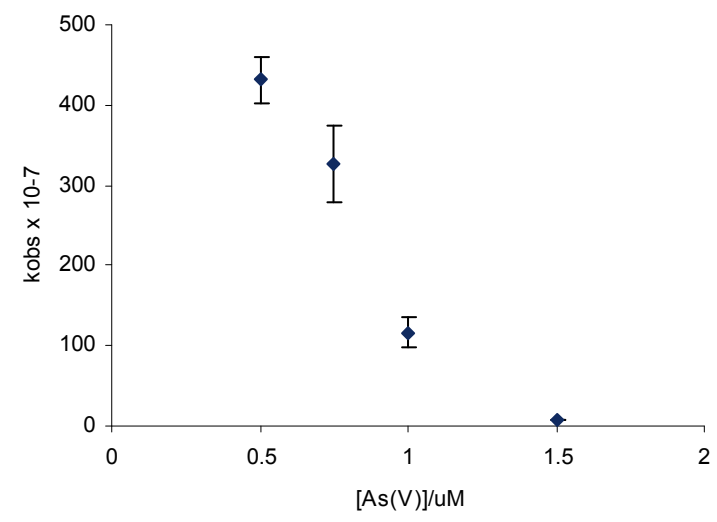

Figure 4

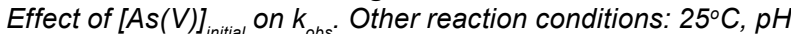
3, $0.75 \mathrm{mg} / \mathrm{l} \mathrm{FA}$, $2.2 \mu \mathrm{M} \mathrm{Fe}(\mathrm{III})$, dark. Analysis was done in triplicate and error bars represent the standard deviations. Standard deviation is within symbol size for data without error bars.

and the data support our hypothesis that reduction occurs via complex formation. This has serious environmental consequences since some of our experimental conditions are similar to groundwater conditions.

\section{Acknowledgements}

This work was done at West Virginia University in the C. Eugene Bennett Department of Chemistry. The writing of the manuscript including revisions was done in the Department of Chemistry, Medical Technology and Physics at Monmouth University. Financial support provided by these departments is greatly appreciated. The authors acknowledge the insightful comments and suggestions from the reviewers.

\section{References}

BONN BA and FISH W (1993) Measurement of electrostatic and sitespecific associations of alkali metal cations with humic acid. J. Soil Sci. 44 335-345.

BRYAN ND, ROBINSON VJ, LIVENS FR, HESKETH N, JONES MN and LEAD JR (1997) Metal humic interactions: A random structural 
modeling approach. Geochim.Cosmochim. Acta 61 805-820.

CHERRY JA, SHAIKH AU, TALLMAN DE and NICHOLSON RV (1979) Arsenic species as an indicator of redox conditions in groundwater. J. Hydrol. (Amsterdam, Netherlands) 43 373-392.

DUTTA PK, PEHKONEN SO, SHARMA VK and RAY AK (2005) Photocatalytic oxidation of arsenic (III): Evidence of hydroxyl radicals. Environ. Sci. Technol. 39 1827-1834.

EMETT MT and KHOE GH (2001) Photochemical oxidation of arsenic by oxygen and iron in acidic solutions. Water Res. 35 649-656.

FUKUSHIMA M and TATSUMI K (1999) Light acceleration of iron(III) reduction by humic acid in the aqueous solution. Colloids and Surfaces, A: Physicochemical and Engineering Aspects 155 249-258.

GABERELL M, CHIN YP, HUG SJ, and SULZBERGER B (2003) Role of dissolved organic matter composition on the photoreduction of $\mathrm{Cr}(\mathrm{VI})$ to $\mathrm{Cr}(\mathrm{III})$ in the presence of iron. Environ. Sci. Technol. 37 4403-4409.

HUG SJ, LAUBSCHER HU and JAMES BR (1997) Iron(III) catalyzed photochemical reduction of chromium(VI) by oxalate and citrate in aqueous solutions. Environ. Sci. Technol. 31 160-170.

KLAENING UK, BIELSKI BHJ and SEHESTED K (1989) Arsenic
(IV). A pulse-radiolysis study. Inorg. Chem. 28 2717-2724.

MUKHOPADHYAY D and SANYAL SK (2004) Complexation and release isotherm of arsenic in arsenic-humic/fulvic equilibrium study. Aust. J. Soil Res. 42 815-824.

REDMAN AD, MACALADY DL and AHMANN D (2002) Natural organic matter affects arsenic speciation and sorption onto hematite. Environ. Sci. Technol. 36 2889-2896.

THIRUNAVUKKARASU OS, VIRARAGHAVAN T and SUBRAMANIAN KS (2003) Arsenic removal from drinking water using granular ferric hydroxide. Water SA 29 (2) 161-170. http://www.wrc. org.za/archives/watersa $\% 20$ archive/2003/april/7.pdf

TONGESAYI T and SMART RB (2006) Arsenic speciation: Reduction of $\operatorname{arsenic}(\mathrm{V})$ to arsenic(III) by fulvic acid. Environ. Chem. $3137-$ 141.

VOELKER BM and SULZBERGER B (1996) Effect of fulvic acid on Fe(II) oxidation by hydrogen peroxide. Environ. Sci. Technol. 30 1106-1114.

WITTBRODT PR and PALMER CD (1996) Effect of temperature, ionic strength, background electrolytes, and $\mathrm{Fe}(\mathrm{III})$ on the reduction of hexavalent chromium by soil humic substances. Environ. Sci. Technol. 30 2470-2477.

\section{APPENDIX: Supporting data}

\section{Effect of FA concentration}

Rate of reduction reaction of $\mathrm{As}(\mathrm{V}), \mathrm{r}$, can be written as follows:

$$
\mathrm{r}=-\mathrm{d}[\mathrm{As}(\mathrm{V})] / \mathrm{dt}=\mathrm{k}_{\mathrm{obs}}[\mathrm{As}(\mathrm{V})]
$$

where:

$$
\mathrm{k}_{\mathrm{obs}} \text { is the pseudo-first-order rate constant. }
$$

Concentration of $\mathrm{As}(\mathrm{V})$ after a certain incubation period is obtained by subtracting the concentration of produced As(III) from the initial concentration of $\mathrm{As}(\mathrm{V})$.

Integrating Eq. (1) gives:

$$
\left.\ln \left\{\left([\mathrm{As}(\mathrm{V})]_{\text {initial }}-[\mathrm{As}(\mathrm{III})]\right) /[\mathrm{As}(\mathrm{V})]_{\text {initial }}\right]\right\}=\mathrm{k}_{\mathrm{obs}} \mathrm{t}
$$

The effect of FA concentration on the reduction kinetics is shown in Fig.1. Values of $\mathrm{k}_{\text {obs }}$ were evaluated from the slopes of the lines according to Eq. (2). No reduction of $A s(V)$ was observed in the absence of FA. The amount of As(V) reduced increased with an increase in the FA concentration.

Rearranging Eq.(1) by considering concentration of FA gives:

$$
\mathrm{r}=-\mathrm{d}[\mathrm{As}(\mathrm{V})] / \mathrm{dt}=\mathrm{k}_{\mathrm{FA}}[\mathrm{As}(\mathrm{V})][\mathrm{FA}]
$$

where:

$\mathrm{k}_{\mathrm{FA}}$ is the empirical second-order rate constant.

From Eq.(1) and Eq.(3):

$$
\mathrm{k}_{\mathrm{FA}}=\mathrm{k}_{\mathrm{obs}} /[\mathrm{FA}]
$$

Eq. (4) shows a linear relationship between $\mathrm{k}_{\mathrm{obs}}$ and FA concentration.

\section{Salt effects}

To determine the effect of a background electrolyte or salt effect on the kinetics of the reduction reaction, $\mathrm{LiCl}$ was used. From work done by Bonn and Fish (1993), lithium cation, of all the alkali metal cations, exhibited no specific binding with humic substances (HA) and was therefore appropriate for the purpose of this work. As shown in Fig. 2, the amount of As(V) reduced by FA decreased with an increase in the concentration of $\mathrm{LiCl}$.
Since $\mathrm{Li}^{+}$ion is not likely to be bound by FA, this observation can be explained in terms of the salt ions interposing themselves between cation binding sites on FA and the anionic $\mathrm{As}(\mathrm{V})$ reducing chances of complex formation which precedes reduction of $\mathrm{As}(\mathrm{V})$.

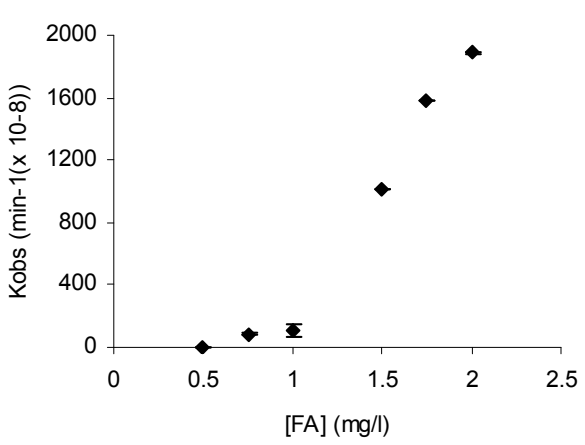

Figure 1

Effect of [FA] on the kinetics of the reduction of $A s(V)$ at $p H 3$ and $25^{\circ} \mathrm{C}$ under dark conditions. Initial reaction conditions: 1.50 $\mu M$ As(V), $2.2 \mu \mathrm{M} \mathrm{Fe}(I I I)$. Standard deviation (triplicate analysis) is within symbol size for data without error bars.

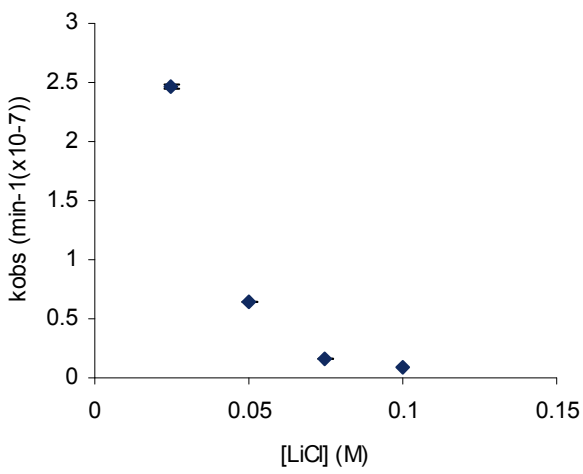

Figure 2

Effect of [ $\mathrm{LiCl}$ on the kinetics of the reaction at $\mathrm{pH} 3$ and $25^{\circ} \mathrm{C}$ under dark conditions. Initial reaction conditions: $0.50 \mu \mathrm{M} \mathrm{As}(\mathrm{V})$, $0.75 \mathrm{mg} / \mathrm{L} \mathrm{FA}, 2.2 \mu \mathrm{M} \mathrm{Fe}(\mathrm{III})$. Standard deviation (triplicate analysis) is within symbol size for data without error bars. 